\title{
PEMECAHAN MASALAH KEMACETAN LALU LINTAS DI PEREMPATAN SUKARNO HATTA - BUAH BATU BANDUNG DENGAN METODE SIMULASI KOMPUTER
}

\section{SOLUTION FOR TRAFFIC IN SOEKARNO HATTA - BUAH BATU ROAD INTERSECTION WITH COMPUTER SIMULATION METHOD}

\author{
Christanto Triwibisono ${ }^{1)}$, Rio Aurachman ${ }^{2)}$ \\ 1)2) Telkom University, J. Telekomunikasi, Bandung, Jawa Barat 40257, Indonesia
}

\section{ARTICLE INFORMATION}

Article history:

Received: Februari 28, 2020

Revised: Maret 17, 2020

Accepted: Mei 31, 2020

Keywords:

Traffic jam

Computer simulation

Pro Model

Kata kunci :

Simulasi,

Promodel,

Kemacetan Lalu Lintas

\begin{abstract}
A B S T R A C T
This paper proposes a solution to the problem of congestion at the Sukarno Hatta Intersection - Buah Batu Bandung by using a computer simulation method with Pro Model software. There are three alternative solutions to this problem, namely changing the duration of traffic lights, adding new road lanes, or making flyovers. Changing the duration of the traffic lights will only reduce the car's travel time from an average of 10.5 minutes to 8.9 minutes ( $85 \%$ of the previous travel time). Adding one lane to each road will only reduce the vehicle's travel time from an average of 10.5 minutes to 7.7 minutes $(73 \%$ of the previous travel time). The construction of a one-way flyover on Jalan Sukarno Hatta is the best solution, because it reduce the vehicle travel timefrom an average of 10.3 minutes to 3.2 minutes. Significant changes have occurred, the travel time is only $32 \%$ of the previous travel time.
\end{abstract}

\section{A B S T R A K}

Makalah ini mengusulkan solusi atas masalah kemacetan di Perempatan Sukarno Hatta - Buah Batu Bandung dengan menggunakan metode simulasi komputer dengan perangkat lunak Pro Model. Ada tiga alternatif solusi masalah ini yaitu mengubah durasi lampu merah dan hijau, menambah jalur jalan baru, atau membuat jalan layang. Pengubahan durasi lampu merah dan hijau hanya akan mengurangi waktu tempuh mobil dari rata-rata 10,5 menit menjadi 8,9 menit ( $85 \%$ dari waktu tempuh sebelumnya). Penambahan satu jalur pada setiap jalan hanya akan mengurangi waktu tempuh kendaraan dari rata-rata 10,5 menit menjadi 7,7 menit $(73 \%$ dari waktu tempuh sebelumnya). Pembuatan jalan layang satu arah di Jalan Sukarno Hatta merupakan solusi terbaik, karena mengurangi waktu tempuh kendaraan untuk dari rata-rata 10,3 menit menjadi 3,2 menit. Terjadi perubahan signifikan, waktu tempuh tinggal $32 \%$ dari waktu tempuh sebelumnya.

This is an open access article under the $\underline{\mathrm{CC}-\mathrm{BY}}$ license.

Corresponding autho

Name : Rio Aurachman

Email : rioaurachman@telkomuniversity.ac.id

\section{PENDAHULUAN}

Kemacetan lalu lintas di Kota Bandung, adalah hal yang sering dihadapi oleh penduduk Kota Bandung. Kemacetan itu umumnya terjadi di persimpangan-persimpangan jalan, apalagi pada jam sibuk yaitu pagi hari ketika para karyawan berangkat kerja atau anak-anak pergi ke sekolah dan sore hari ketika mereka pulang..

Salah satu titik kemacetan yang sering terjadi di Kota Bandung adalah di perempatan Jalan Buah 
Batu dengan Jalan Sukarno Hatta. Tingkat kemacetan ini terjadi karena banyaknya kendaraan yang menuju kota dari berbagai perumahan yang berada di pinggiran kota. Kendaraan dari arah Kantor SAMSAT berasal dari perumahan di Bandung Timur, kendaraan dari arah Terusan Buah batu berasal dari perumahan di Bandung Selatan (Kecamatan Dayeuh Kolot), kendaraan dari arah Jalan Buah Batu berasal dari Kota Bandung, dan kendaraan dari arah Leuwi Panjang berasal dari Bandung Barat, Jalan Moh.Toha, dan Wilayah Kopo.

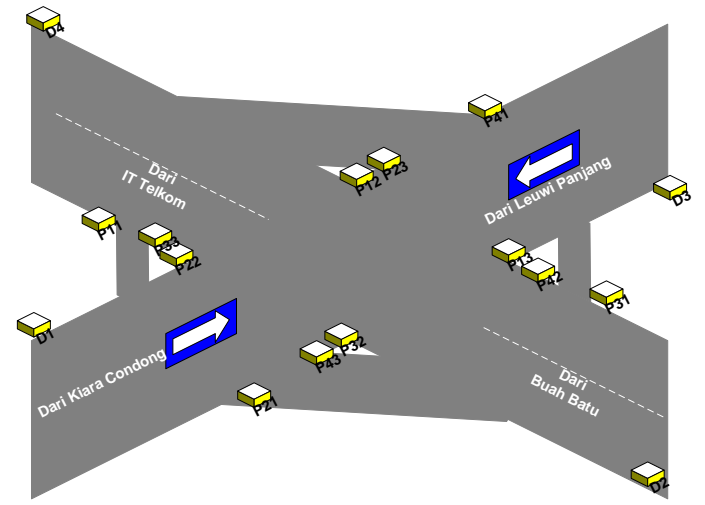

Gambar 1 Peta Perempatan Buah Batu, Bandung

Gambar 1 menunjukkan kondisi perempatan Jl. Soekarno Hatta (dari Arah Jalan Kiara Condong), arah ke sebelah kiri akan menuju ke Telkom University, arah lurus akan menuju ke Terminal Leuwi Panjang, dan arah ke kanan akan menuju ke Jl. Buah Batu. Kendaraan yang akan menuju Telkom University tidak terpengaruh secara langsung oleh lampu lalu lintas. Semua jalan di perempatan ini memiliki median jalan yang berfungsi agar konflik lalu lintas tidak terjadi antara kendaraan berlawanan arah.

Di pagi hari, kemacetan paling parah adalah dari arah Kantor SAMSAT. Apabila pengguna jalan berada 500 meter dari perempatan jalan itu dengan menggunakan mobil pada pukul 6.45 7.15 pagi dari arah Kantor SAMSAT menuju Jalan Buah Batu,yaitu dibutuhkan waktu rata-rata 10,5 menit untuk melalui perempatan jalan itu. Ke arah Leuwi Panjang dibutuhkan waktu rata-rata 9,3 menit, sedangkan ke arah Jalan Terusan Buah Batu dibutuhkan waktu rata-rata 6,2 menit. Kemacetan dari arah Jalan Buah batu, Terusan Buah Batu, dan Leuwi Panjang tidak terlalu parah.

Penyebab terjadinya kemacetan adalah pertumbuhan jumlah kendaraan yang lebih tinggi dibandingkan pertumbuhan panjang dan lebar jalan, manajemen lalu lintas yang kurang optimum, kondisi jalan yang kurang baik, disiplin pengguna jalan yang kurang baik, dan lain-lain [1]. Penelitian ini tidak akan membahas mengenai perbaikan kondisi jalan dan perbaikan disiplin para pengguna jalan.

Alternatif-alternatif yang akan digunakan untuk memecahkan masalah kemacetan di Perempatan Sukarno Hatta dan Buah Batu Bandung adalah dengan mengubah waktu lampu lalu lintas, menambah jalur, atau membuat jalan layang. Untuk memudahkan pengujian ketiga alternatif tersebut dengan murah, maka digunakan simulasi dengan menggunakan komputer

Beberapa riset terdahulu telah memberikan alternatif solusi dan metode untuk pemecahan kasus antrian di perempatan jalan. Beberapa riset terdahulu diantaranya menggunakan perangkat lunak Matlab [2], Arena [3], Vissim [4], dan Simulink [5]. Adapun metode yang digunakan meliputi Fuzy Logic [6], Monte Carlo [7], dan Discrete Event Simulation. Beberapa pengayaan juga dikontribusikan oleh riset terdahulu, diantaranya adalah menggunakan Programmable Logic Control [8], Visualisasi HMI [9], dan Automata [10]. Beberapa penelitian memberikan kesimpulan rekomendai solusi yang berbeda. Satu penelitian misalnya mengusulkan mengubah durasi lampu lalu lintas dan mengubah arah pergerakan kendaraan dengan pemberlakuan larangan belok kanan [3]. Sedangkan riset lainnya mengusulkan penerapan parameter konfigurasi dalam pengaturan perempatan jalan [7]

Penelitian ini mencoba berkontribusi dengan pendekatan Discrete Event Simulation menggunakan perangkat lunak Promodel. Promodel digunakan karena tingkat ketelitiannya tinggi sehingga dapat diperoleh hasil yang akurat, mudah digunakan (User friendly), serta dapat menghasilkan animasi, sehingga mudah difahami dan dianalisis [11]

\section{METODE PENELITIAN}

Pada bagian ini dijelaskan teori-teori dan metodologi yang digunakan untuk memecahkan masalah diatas yaitu tentang simulasi dan transportasi. 


\subsection{Simulasi Komputer}

Simulasi adalah tiruan dari suatu sistem [12]. Simulasi komputer adalah penggunaan komputer untuk meniru operasi berbagai fasilitas / proses yang ada di dunia nyata atau tiruan suatu sistem yang berubah seiring dengan perubahan waktu [13]. Terminologi simulasi umumnya digunakan pada konteks simulasi dinamik (simulasi suatu sistem yang kondisinya berubah sesuai dengan perubahan waktu).

Simulasi banyak digunakan apabila suatu sistem merupakan system yang terlalu rumit sehingga tidak dapat dibuat model yang dapat dievaluasi secara analitis. Oleh karena itu solusi yang diperoleh bukanlah solusi yang optimum, tetapi mendekati optimum. Selain itu simulasi juga digunakan apabila biaya yang dibutuhkan untuk membangun sistem nyata terlalu mahal atau apabila kita tidak mungkin melakukan eksperimen di dunia sesungguhnya karena berbahaya atau berpotensi menimbulkan ketidakpuasan bagi orang-orang yang terlibat di sistem tersebut.

Simulasi discrete event adalah suatu simulasi yang perubahan status sistemnya terjadi pada waktu-waktu tertentu yang diskrit yang distimulus oleh suatu kejadian (event). Waktu terjadinya perubahan status di masa yang akan datang ditentukan, disebut juga jam simulasi. Simulasi seperti ini mendominasi penerapan simulasi komputer [14]

\subsection{Validasi Model Simulasi}

Validasi model simulasi adalah aktivitas untuk memeriksa apakah model simulasi yang dibuat merupakan model yang mirip/ mewakili sistem yang berjalan di dunia nyata. Aktivitas ini merupakan aktivitas yang sangat penting dan sangat menyita waktu. Validasi yang dilakukan hanyalah validitas fungsinya saja, tanpa diperoleh validitas absolut [11].

Banyak teknik yang digunakan untuk melakukan validasi [11] antara lain dengan melihat animasi yang terjadi dari model, membandingkan dengan sistem aktual, menguji dengan data historis, dan lain-lain.

\subsection{Kemacetan Lalu Lintas}

Kemacetan lalu lintas disebabkan oleh meningkatnya jumlah kendaraan, tetapi tidak diimbangi dengan peningkatan infrastruktur serta perbaikan perilaku para pengguna jalan. Kemacetan lalu lintas mengakibatkan kecepatan kendaraan berkurang, waktu perjalanan yang lebih lama, konsumsi BBM (Bahan Bakar Minyak) yang besar, dan emisi bahan bakar yang merusak lingkungan. Untuk memecahkan masalah ini diperlukan usaha yang serius [15]. Solusi tradisional untuk memecahkan kemacetan lalu lintas adalah membangun jalan [16]. Selain itu kemacetan lalu lintas dapat dipecahkan dengan berbagai cara antara lain dengan menerapkan perbaikan layanan transportasi umum, dukungan agar masyarakat lebih menyukai jalan kaki atau naik sepeda, dan lainlain.

\subsection{Validasi Model Simulasi}

Metode validasi terbaik untuk model simulasi yang menggunakan data lalu lintas adalah dengan menggunakan rumus statistik GEH [17]. Rumus statistik GEH ditemukan oleh Geoffrey E. Havers. Metode ini membandingkan data hasil simulasi dengan data hasil pengamatan.

$$
\text { GEH }=\sqrt{\frac{\left(q_{\text {simulated }}-q_{\text {observed }}\right)^{2}}{0,5 \times\left(q_{\text {simulated }}+q_{\text {observed }}\right)}}
$$

dimana:

$\mathrm{q}_{\text {simulated }}=$ data hasil simulasi

$\mathrm{q}_{\text {observed }}=$ data hasil pengamatan

Rumusan di atas merupakan rumus statistik yang dimodifikasi oleh Geoffrey E. Havers dari Chisquared dengan menggabungkan perbedaan antara nilai mutlak dengan nilai relatif. Makna dari nilai error GEH dapat dilihat pada Tabel 1.

Tabel 1. Makna Nilai Error GEH

\begin{tabular}{cc}
\hline Nilai GEH & Makna \\
\hline GEH $<5,0$ & Diterima \\
$5<=\mathrm{GEH}<=10$ & $\begin{array}{c}\text { Peringatan: Model error } \\
\text { atau data buruk } \\
\text { DEH }>10\end{array}$ \\
\hline
\end{tabular}

\section{HASIL DAN PEMBAHASAN}

\subsection{Pengumpulan Data}

Data di ambil pada hari Senin pukul 06.00 08.00 di titik-titik seperti terlihat di Gambar 1. Diasumsikan tidak terjadi perubahan signifikan terkait proprosi arus kendaraan pada beberapa 
tahun terakhir. Waktu yang dipilih tersebut juga adalah waktu dengan tingkat kepadatan lalu lintas tertinggi.

- D1 - kedatangan dari Kiara Condong: di Jl. Sukarno Hatta depan rumah makan Cibiuk (500 meter dari perempatan jalan).

- P11 - Meninggalkan perempatan menuju ke Telkom University (Tel-U)

- P12 - Meninggalkan perempatan menuju ke Leuwi Panjang

- P13 - Meninggalkan perempatan menuju ke Buah Batu

- D2 - kedatangan dari Buah Batu: di Buah Batu(sebelum belokan Jl. Guntur Sari Wetan)

- P21 - Meninggalkan perempatan menuju ke Kiara Condong

- P22 - Meninggalkan perempatan menuju ke Telkom University

- P23 - Meninggalkan perempatan menuju ke Buah Batu

- D3 - kedatangan dari Leuwi Panjang:

- P31-Meninggalkan perempatan menuju ke Buah Batu

- P32 - Meninggalkan perempatan menuju ke Kiara Condong

- P33 - Meninggalkan perempatan menuju ke Telkom University

- D4 - kedatangan dari Telkom University:

- P41 - Meninggalkan perempatan menuju ke Leuwi Panjang

- P42 - Meninggalkan perempatan menuju ke Buah Batu

- P43 - Meninggalkan perempatan menuju ke Kiara Condong

Tabel 2 ada 1.064 unit, yang ke Buah Batu ada 1. menunjukkan bahwa pukul $6.45-7.15$ adalah data lalu lintas terpadat. Jumlah mobil yang ke Leuwi Panjang 671 unit, dan yang ke Telkom University ada 967 unit. Data pada waktu inilah yang akan digunakan untuk memvalidasi model eksisting dan akan digunakan untuk memeriksa performansi model usulan.

Tabel 2. Jumlah Mobil yang Keluar dari Arah Kiara Condong

\begin{tabular}{cccc}
\hline & \multicolumn{3}{c}{ Jumlah Mobil (Unit) } \\
\cline { 2 - 4 } Waktu & $\begin{array}{c}\text { Ke Leuwi } \\
\text { Panjang }\end{array}$ & $\begin{array}{c}\text { Ke Buah } \\
\text { Batu }\end{array}$ & $\begin{array}{c}\text { Ke Telkom } \\
\text { University }\end{array}$ \\
\hline $6.00-6.15$ & 322 & 670 & 278 \\
$6.15-6.30$ & 365 & 755 & 289 \\
$6.30-6.45$ & 496 & 763 & 331 \\
\hline
\end{tabular}

\begin{tabular}{llll}
\hline $6.45-7.00$ & 527 & 844 & 458 \\
$7.00-7.15$ & 537 & 827 & 459 \\
$7.15-7.30$ & 513 & 774 & 304 \\
$7.30-7.45$ & 502 & 760 & 299 \\
$7.45-8.00$ & 467 & 631 & 295 \\
\hline
\end{tabular}

Sumber: Pengamatan Lapangan

Tabel 3 menunjukkan bahwa pukul $6.45-7.15$ adalah waktu rata-rata terlama yang harus dihadapi oleh mobil untuk melewati perempatan. Lama rata-rata durasi waktu kendaraan pada perempatan jalan yang akan ke Leuwi Panjang adalah $(527 * 9,73+537 * 9,78) /(527+537)=$ 9,76 menit, lama rata-rata waktu tunggu mobil yang akan ke Buah Batu adalah $(844 * 10,83+$ $827 * 10,78) /(844+827)=10,81$ menit, dan lama rata-rata durasi waktu mobil yang akan ke Telkom University adalah $(458$ * $6,45+459$ * $6,46) /(458+459)=6,46$ menit. Rata-rata waktu inilah yang akan digunakan untuk memvalidasi model eksisting dan akan digunakan untuk memeriksa performansi model usulan.

Tabel 3. Lama Rata-rata Mobil di dalam Sistem

\begin{tabular}{cccc}
\hline & \multicolumn{3}{c}{$\begin{array}{c}\text { Lama Rata-rata di Perempatan } \\
\text { (Menit) }\end{array}$} \\
\cline { 2 - 4 } Waktu & $\begin{array}{c}\text { Ke Leuwi } \\
\text { Panjang }\end{array}$ & $\begin{array}{c}\text { Ke Buah } \\
\text { Batu }\end{array}$ & $\begin{array}{c}\text { Ke Telkom } \\
\text { University }\end{array}$ \\
\hline $6.00-6.15$ & 4,96 & 6,75 & 3,41 \\
$6.15-6.30$ & 5,75 & 8,16 & 3,97 \\
$6.30-6.45$ & 9,08 & 9,77 & 4,56 \\
$6.45-7.00$ & 9,73 & 10,83 & 6,45 \\
$7.00-7.15$ & 9,78 & 10,78 & 6,46 \\
$7.15-7.30$ & 9,41 & 9,97 & 4,17 \\
$7.30-7.45$ & 8,76 & 8,84 & 3,93 \\
$7.45-8.00$ & 7,53 & 7,78 & 3,79 \\
\hline
\end{tabular}

Sumber: Pengamatan Lapangan

\subsection{Pengembangan Model}

Berdasarkan kondisi perempatan jalan sebagaimana tertuang pada Gambar 1, maka dibuatlah layout simulasi menggunakan promodel pada gambar 2 . 


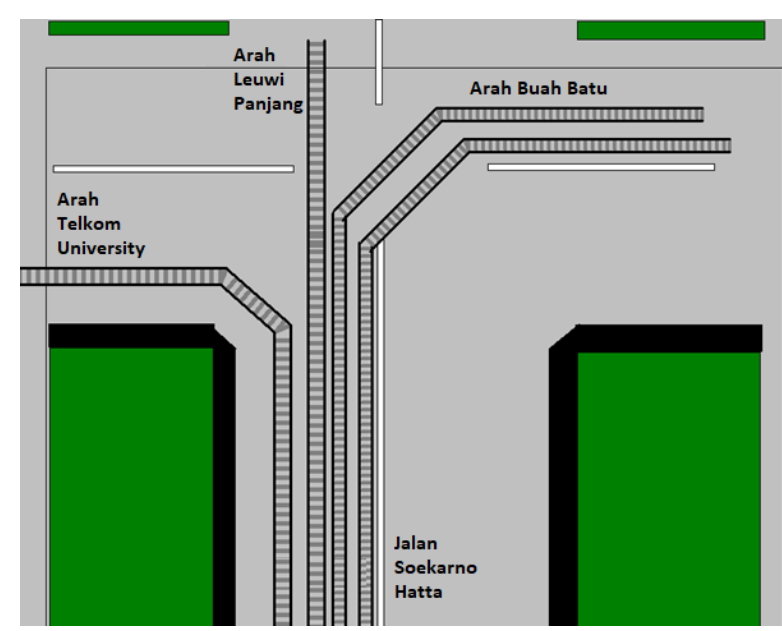

Gambar 2. Layout simulasi menggunakan Routing Paths

Sistem relevan yang menjadi objek kajian dalam penelitian ini adalah perempatan jalan saja. Simulasi tidak mempertimbangkan keberedaan dari pertigaan yang berjarak jauh dari perempatan jalan.

Gambar 3 menunjukkan entitas-entitas (objek yang akan diproses) yang diperlukan untuk memecahkan masalah ini.

\begin{tabular}{|c|c|c|}
\hline \multicolumn{3}{|c|}{ Entities } \\
\hline Icon & Name & \\
\hline 3 & mobil_dtg & \\
\hline & motor & \\
\hline & mobil_bubat & \\
\hline & mobil_leuwi_panjang & \\
\hline 6 & mobil_itt & \\
\hline & motor_itt & 5 \\
\hline$\leq$ & motor_leuwi_panjang & 5 \\
\hline$\leq$ & motor_bubat & 5 \\
\hline
\end{tabular}

Gambar 3. Tampilan Entities

Entitas tersebut yaitu mobil_dtg (mobil yang datang di jalan Sukarno Hatta, depan Rumah Makan Cibiuk) yang kemudian akan berubah sesuai dengan arah yang diambil mobil tersebut menjadi mobil_bubat yang ke arah buah batu, mobil_leuwi_panjang yang ke arah Leuwi Panjang, dan mobil telu yang ke arah telkom university. Lama rata-rata waktu berada di dalam sistem untuk mobil dari arah Telkom University di perempatan Soekarno Hatta - Buah Batu adalah 6,87 menit, dari arah Leuwi Panjang 5,33 menit, dan dari arah Buah Batu 2,46 menit, sedangkan dari arah Kiara Condong 10,81 menit, sehingga masalah yang mendesak untuk dipecahkan adalah kemacetan dari arah Kiara Condong.

\begin{tabular}{|c|c|c|}
\hline \multicolumn{3}{|l|}{$\square$ Locations } \\
\hline Icon & Name & Cap. \\
\hline 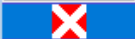 & Sukarno_Hatta & INFINITE \\
\hline IIIIIIIIIIIII & J1_Sukarno_Hatta & INFINITE \\
\hline IIIIIIIIIII & arah_leuwi_panjang & INFINITE \\
\hline & arah_buah_batu & INFINITE \\
\hline IIIIIIIIII & arah_buah_batu.1 & INFINITE \\
\hline IIIIIIIIIII & arah_buah_batu.2 & INFINITE \\
\hline & J1_bubat_mobil & INFINITE \\
\hline IIIIIIIIIII & J1_bubat_mobil.1 & INFINITE \\
\hline IIIIIIIIIIII & J1_bubat_mobil.2 & INFINITE \\
\hline IIIIIIIIIIII & arah_itt_mobil & INFINITE \\
\hline 피피피 & jalan_Sukhat_motor & INFINITE \\
\hline IIIIIIIIIIII & arah_leuwi_panjang_motor & INFINITE \\
\hline IIIIIIIIIII & arah_buah_batu_motor & INFINITE \\
\hline IIIIIIIIIII & jalan_buah_batu_motor & INFINITE \\
\hline IIIIIIIIIIII & arah_itt_motor & INFINITE \\
\hline $\mathrm{Aa}$ & Locl & 1 \\
\hline $\mathrm{Aa}$ & Loc2 & 1 \\
\hline 피피피픈 & Jalan_Sukhat_Motor2 & INFINITE \\
\hline IIIIIIIIII & ARAH_leuwi_panjang_Motor2 & INFINITE \\
\hline
\end{tabular}

\section{Gambar 4 Tampilan Location}

Gambar 4 menunjukkan lokasi-lokasi yang digunakan untuk memecahkan masalah ini yang terdiri dari Jalan Sukarno Hatta tempat mobil datang, satu jalur jalan yang menuju ke arah Leuwi Panjang, dua jalur jalan yang menuju ke arah Buah Batu, dan satu jalur jalan yang menuju ke arah Telkom University. Gambar 5 menggambarkan tampilan proses dan Gambar 6 menjelaskan tentang simulation option yang akan digunakan.

\begin{tabular}{|c|c|c|}
\hline$\Rightarrow$ Process & & [3] $\quad$ [ \\
\hline Entity... & Location... & Operation... \\
\hline mobil_dtg & Sukarno_Hatta & $\mathrm{n} 1=\operatorname{clock}(\mathrm{sec})$ \\
\hline mobil_leuwi_panjang & J1_Sukarno_Hatta & \\
\hline mobil_bubat & arah_buah_batu & \\
\hline mobil_leuwi_panjang & arah_leuwi_panjang & $\mathrm{n} 1=\operatorname{clock}(\mathrm{sec})$ wait until (n1 \\
\hline mobil_bubat & J1_bubat_mobil & $\mathrm{n} 1=\operatorname{clock}$ (sec) wait until (n1 \\
\hline mobil_itt & arah_itt_mobil & \\
\hline motor & Sukarno_Hatta & $\mathrm{n} 1=\operatorname{clock}(\mathrm{sec})$ \\
\hline motor_itt & jalan_Sukhat_motor & \\
\hline motor_leuwi_panjang & arah_buah_batu_motor & \\
\hline motor_itt & arah_leuwi_panjang_mo & $\mathrm{n} 1=\operatorname{clock}(\mathrm{sec}$ ) wait until (n1 \\
\hline motor_leuwi_panjang & jalan_buah_batu_motor & $\mathrm{n} 1=\operatorname{clock}(\mathrm{sec})$ wait until (n1 \\
\hline motor_bubat & arah_itt_motor & \\
\hline motor_itt & Jalan_Sukhat_Motor2 & \\
\hline motor_itt & ARAH_leuwi_panjang_Mo & $\mathrm{n} 1=\operatorname{clock}(\mathrm{sec})$ wait until (n1 \\
\hline motor_bubat & arah_itt_motor & \\
\hline
\end{tabular}

\section{Gambar 5 Tampilan Proses}

\subsection{Validasi Model Eksisting}

Validasi model dilakukan dengan membandingkan data yang diperoleh pada saat pengumpulan data dengan hasil simulasi, menghitung nilai GEH dan memastikan nilainya lebih kecil dari 5 (lima), dan memeriksa apakah animasi simulasi mirip dengan sistem yang berjalan saat ini.) 


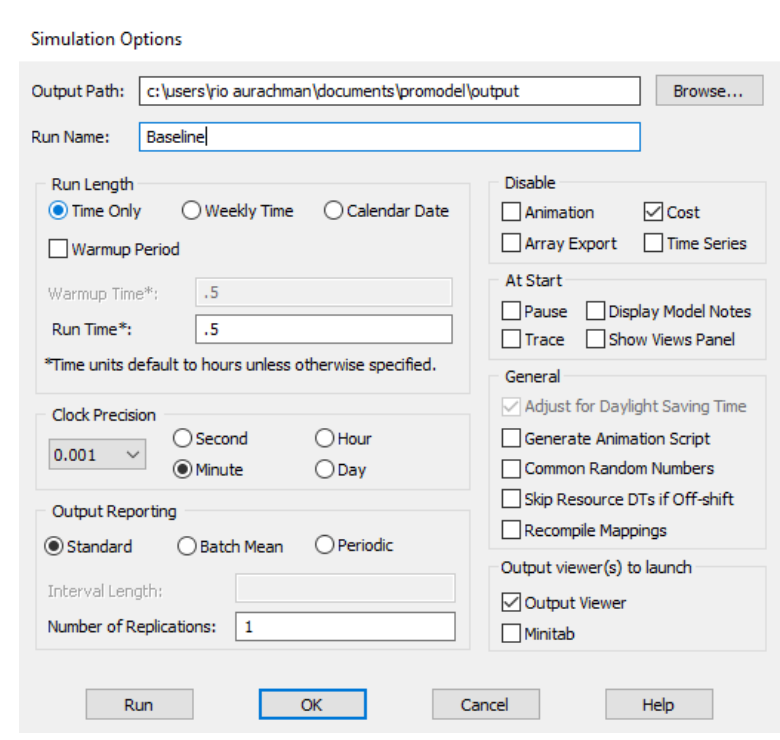

Gambar 6. Tampilan Simulation Option

Tabel 4 menunjukkan perbandingan antara data yang diperoleh pada saat pengumpulan data dengan hasil simulasi. Lama mobil dalam sistem yang menuju ke Leuwi Panjang berdasarkan hasil pengumpulan data 9,76 menit sama dengan hasil simulasi, yang menuju Buah Batu berdasarkan hasil pengumpulan data 10,81 menit sedangkan hasil simulasi 10,68 menit, dan yang menuju Telkom University berdasarkan hasil pengumpulan data 6,46 menit sedangkan hasil simulasi 6,44 menit. Jumlah mobil yang keluar dari perempatan menuju ke Leuwi Panjang berdasarkan hasil pengumpulan data 1,064 buah sedangkan hasil simulasi 1,078 buah, yang ke Buah Batu berdasarkan hasil pengumpulan data 1,671 buah sedangkan hasil simulasi 1,707 buah, dan yang menuju Telkom University berdasarkan hasil pengumpulan data 917 buah sedangkan hasil simulasi 941 buah.

Untuk memeriksa apakah simulasi yang dibuat mewakili sistem yang berjalan saat ini, maka dilihat animasi yang dibuat, serta dilakukan perbandingan antara output simulasi dengan data aktual. Animasi dari simulasi di komputer telah berjalan sesuai dengan sistem saat ini, ditunjukkan dengan jalur kiri (menuju ke Telkom University) yang berjalan terus menerus, jalur tengah (menuju Leuwi Panjang) dan kanan (menuju Buah Batu) berhenti, kemudian bersama-sama berjalan, selanjutnya jalur kanan berhenti lebih dahulu baru diikuti oleh jalur tengah.

Perbandingan antara data aktual dengan hasil simulasi dapat dilihat pada Tabel 4 Terlihat semua data $\mathrm{GEH}<5$, artinya model simulasi valid (diterima)
Tabel 4. Perbandingan Hasil Simulasi dengan Pengumpulan Data

\begin{tabular}{|c|c|c|c|c|}
\hline & Data & Simulas & GEH & Catatan \\
\hline \multicolumn{5}{|c|}{ Lama di Sistem (Mobil) (Menit) } \\
\hline Ke Leuwi & & & & \\
\hline $\begin{array}{l}\text { Panjang } \\
\text { Ke Buah }\end{array}$ & 9,76 & 9,76 & 0,00 & Diterima \\
\hline $\begin{array}{l}\text { Batu } \\
\text { Ke Telkom }\end{array}$ & 10,81 & 10,68 & 0,04 & Diterima \\
\hline University & 6,46 & 6,44 & 0,01 & Diterima \\
\hline \multicolumn{5}{|c|}{ Jumlah Mobil (Unit) } \\
\hline $\begin{array}{l}\text { Ke Leuwi } \\
\text { Panjang } \\
\text { Ke Buah }\end{array}$ & 1,064 & 1,078 & 0,43 & Diterima \\
\hline $\begin{array}{l}\text { Batu } \\
\text { Ke Telkom }\end{array}$ & 1,671 & 1,707 & 0,88 & Diterima \\
\hline University & 917 & 941 & 0,79 & Diterima \\
\hline
\end{tabular}

\subsection{Simulasi pada Alternatif Solusi}

Alternatif-alternatif yang akan digunakan untuk memecahkan masalah kemacetan lalu lintas di Perempatan Sukarno Hatta - Buah Batu Bandung adalah dengan mengubah durasi lalu lintas, menambah jalur atau membuat jalan layang. Pencarian alternatif terbaik dari ketiga alternatif tersebut dilakukan dengan menggunakan simulasi komputer

Saat dilakukan penelitian, lama lampu merah untuk jalur kanan (menuju Buah Batu) adalah 160 (seratus enam puluh) detik, sedangkan lama lampu hijaunya 80 (delapan puluh) detik. Untuk jalur lurus (menuju Leuwi Panjang), lama lampu merah $=140$ (seratus empat puluh) detik dan lama lampu hijau $=100$ (seratus) detik. Total siklus lampu lalu lintas untuk ke dua arah adalah 240 (dua ratus empat puluh) detik. Lama siklus ini tidak diubah dan sesuai yang berfungsi di lokasi dengan asumsi siklus ini adalah siklus yang optimal. Alternatif solusi pertama adalah pengubahan lama lampu merah dan hijau dengan tetap memenuhi constraint siklus yang optimal. Siklus yang dimaksud adalah durasi menyala dari lampu merah ditambah durasi lampu hijau menyala.

Lama lampu merah untuk jalur kanan (menuju Buah Batu) diubah menjadi 120 (seratus dua puluh) detik dan lama lampu hijaunya 120 (delapan puluh) detik. Jalur lurus (menuju Leuwi Panjang), lama lampu merah $=90$ (sembilan puluh) detik dan lama lampu hijau $=150$ (seratus lima puluh) detik.

Dapat dilihat pada Tabel 5 bahwa perubahan hanya akan mengubah waktu tempuh mobil yang melalui lampu lalu lintas tersebut menuju Jalan Buah Batu dari rata-rata 10,81 menit menjadi 
10,04 menit (berkurang 7,13\%). Waktu tempuh mobil yang melalui lampu lalu lintas tersebut menuju Leuwi Panjang dari rata-rata 9,76 menit menjadi 8,87 menit (berkurang 9,12\%). Waktu tempuh masih terlalu lama, selain itu penambahan lama lampu hijau dari satu arah pun akan memperlama waktu menunggu kendaraan dari arah yang lain

Tabel 5 Perbandingan Hasil Simulasi Sistem Saat Ini dengan Hasil Simulasi Alternatif 1

\begin{tabular}{|c|c|c|c|c|}
\hline & Eksisting & Solusi & Selisih & $\%$ \\
\hline \multicolumn{5}{|c|}{ Lama di Sistem (Mobil) } \\
\hline $\begin{array}{l}\text { Ke Leuwi } \\
\text { Panjang }\end{array}$ & 9,76 & 8,87 & 0,89 & $9,12 \%$ \\
\hline $\begin{array}{c}\text { Ke Buah } \\
\text { Batu } \\
\text { Ke }\end{array}$ & 10,81 & 10,04 & 0,77 & $8,12 \%$ \\
\hline $\begin{array}{l}\text { Telkom } \\
\text { University }\end{array}$ & 6,46 & 6,44 & 0,02 & $0,31 \%$ \\
\hline \multicolumn{5}{|c|}{ Jumlah Mobil } \\
\hline $\begin{array}{l}\text { Ke Leuwi } \\
\text { Panjang }\end{array}$ & 1,064 & 1124 & -60 & $5,64 \%$ \\
\hline $\begin{array}{c}\text { Ke Buah } \\
\text { Batu } \\
\text { Ke }\end{array}$ & 1,671 & 1750 & -79 & $4,73 \%$ \\
\hline $\begin{array}{l}\text { Telkom } \\
\text { University }\end{array}$ & 917 & 941 & 24 & $2,62 \%$ \\
\hline
\end{tabular}

Pada alternatif ke dua, penambahan jalur yang mungkin adalah satu jalur untuk setiap arah karena daerah itu telah padat oleh pemukiman / perkantoran. Dapat dilihat pada tabel 6 . bahwa penambahan satu jalur pada setiap jalan hanya akan mengubah waktu tempuh mobil untuk melalui lampu merah menuju Jalan Buah Batu dari rata-rata 10,81 menit menjadi 7,43 menit (turun $31.27 \%$ ). Sedangkan waktu tempuh mobil untuk melalui lampu merah menuju Leuwi Panjang turun dari rata-rata 9,76 menit menjadi 5,27 menit (turun $46 \%$ ).

Tabel 6 Perbandingan Hasil Simulasi Sistem Saat Ini dengan Hasil Simulasi Alternatif 2

\begin{tabular}{|c|c|c|c|c|}
\hline & Eksisting & Solus & Selisih & $\%$ \\
\hline \multicolumn{5}{|c|}{ Lama di Sistem (Mobil) } \\
\hline $\begin{array}{l}\text { Ke Leuwi } \\
\text { Panjang }\end{array}$ & 9,76 & 5,27 & 4,49 & $46,0 \%$ \\
\hline $\begin{array}{c}\text { Ke Buah } \\
\text { Batu } \\
\text { Ke }\end{array}$ & 10,81 & 7,43 & 3,38 & $\begin{array}{l}31,27 \\
\%\end{array}$ \\
\hline $\begin{array}{l}\text { Telkom } \\
\text { Universit }\end{array}$ & 6,46 & 6,44 & 0,02 & $0,31 \%$ \\
\hline \multicolumn{5}{|c|}{ Jumlah Mobil } \\
\hline Ke Leuwi & 1,064 & 1,116 & 52 & $4,89 \%$ \\
\hline
\end{tabular}

\begin{tabular}{|c|c|c|c|c|}
\hline & Eksisting & Solusi & Selisih & $\%$ \\
\hline Panjang & & & & \\
\hline $\begin{array}{c}\text { Ke Buah } \\
\text { Batu } \\
\text { Ke }\end{array}$ & 1,671 & 1,708 & 37 & $2,21 \%$ \\
\hline $\begin{array}{l}\text { Telkom } \\
\text { Universit }\end{array}$ & 917 & 941 & 24 & $2,62 \%$ \\
\hline
\end{tabular}

Alternatif ke tiga dapat dilaksanakan dengan berbagai cara, misalnya: pembuatan jalan layang seperti di Persimpangan Semanggi Jakarta, jalan layang simpang susun (satu di Jalan Sukarno Hatta dan satu lagi di Jalan Buah Batu), jalan layang satu arah di Jalan Sukarno Hatta, jalan layang satu arah di Jalan Buah Batu, dan berbagai kombinasi lainnya.

Pembuatan jalan layang seperti di persimpangan Semanggi Jakarta merupakan solusi yang ideal, tetapi membutuhkan dana yang besar. Demikian pula jalan layang simpang susun di Jalan Sukarno Hatta dan di Jalan Buah Batu. Alternatif lain yang dapat dilaksanakan dengan biaya lebih murah adalah jalan layang satu arah di Jalan Sukarno Hatta atau jalan layang satu arah di Jalan Buah Batu.

Jalan layang satu arah di Jalan Sukarno Hatta menuju Jalan Buah Batu akan membantu memecahkan masalah kemacetan di pagi hari. Sedangkan jalan layang satu arah dari Jalan Buah Batu ke arah Telkom University akan membantu memecahkan masalah kemacetan di sore hari. Karena hal yang paling menimbulkan masalah adalah kemacetan di pagi hari, maka dilakukan simulasi pembuatan jalan layang satu arah dari Jalan Sukarno Hatta ke arah Jl. Buah Batu dan ke arah Leuwi Panjang.

Hasil simulasi jalan layang satu arah dari Jalan Sukarno Hatta menuju Leuwi Panjang dan Buah Batu mengubah waktu tempuh mobil untuk melalui lampu merah menuju Jalan Buah Batu dari rata-rata 10,3 menit menjadi 4,64 menit, sebagaimana tertuang pada Tabel 7.

Tabel 7 Perbandingan Hasil Simulasi Sistem Saat Ini dengan Hasil Simulasi Alternatif 3

\begin{tabular}{ccccc}
\hline & Eksisting & Solusi & Selisih & $\%$ \\
\hline \multicolumn{5}{c}{ Lama di Sistem (Mobi) } \\
$\begin{array}{c}\text { Ke Leuwi } \\
\text { Panjang }\end{array}$ & 9,76 & 4,28 & 5,48 & $56,15 \%$ \\
$\begin{array}{c}\text { Ke Buah } \\
\text { Batu }\end{array}$ & 10,81 & 4,64 & 6,17 & $57,08 \%$ \\
$\begin{array}{c}\text { Ke Telkom } \\
\text { University }\end{array}$ & 6,46 & 4,29 & 2,17 & $33,59 \%$ \\
\hline
\end{tabular}




\begin{tabular}{ccccc}
\hline & Eksisting & Solusi & Selisih & $\%$ \\
\hline \multicolumn{5}{c}{ Jumlah Mobil } \\
$\begin{array}{c}\text { Ke Leuwi } \\
\begin{array}{c}\text { Panjang } \\
\text { Ke Buah }\end{array}\end{array}$ & 1,064 & 1174 & 110 & $10,34 \%$ \\
$\begin{array}{c}\text { Batu } \\
\text { Ke Telkom } \\
\text { University }\end{array}$ & 1,671 & 1818 & 147 & $8,80 \%$ \\
\hline
\end{tabular}

Dari hasil simulasi terkait, didapatkan data perubahan signifikan, waktu tempuh turun $57.08 \%$ dari waktu tempuh aktual. Waktu tempuh mobil untuk melalui lampu lalu lintas menuju Leuwi Panjang turun dari rata-rata 9,76 menit menjadi 4,28 menit. Terjadi penurunan signifikan, waktu tempuh turun sebesar $56.15 \%$

\section{KESIMPULAN}

Alternatif solusi kemacetan pagi hari diperempatan Jalan Sukarno Hatta - Buah Batu dari arah SAMSAT adalah pembuatan jalan layang satu arah dari arah Kantor SAMSAT ke arah Jl. Buah Batu dan Leuwi Panjang. Hasil simulasi menunjukkan pembuatan jalan layang mengubah waktu tempuh mobil yang melalui lampu lalu lintas menuju Jalan Buah Batu dari rata-rata 10,81 menit menjadi 4,64 menit. Terjadi penurunan signifikan, waktu tempuh turun sebesar $57.08 \%$ dari waktu tempuh aktual. Waktu tempuh mobil untuk melalui lampu lalu lintas menuju Leuwi Panjang turun dari rata-rata 9,76 menit menjadi 4,28 menit. Terjadi penurunan signifikan, waktu tempuh turun sebesar $56.15 \%$

Penelitian selanjutnya dapat dilaksanakan dengan mensimulasikan pengaruh motor, mengintegrasikan seluruh jalan, pengambilan data dilakukan selama satu minggu, satu bulan atau satu tahun dengan memperhatikan waktu yang paling sibuk, serta dilakukan analisis kelayakan atas solusi ini sehingga manfaat yang diperoleh masyarakat lebih tinggi dari biaya yang dikeluarkan oleh negara.

\section{DAFTAR PUSTAKA}

[1] W. Mustikarani and S., "Analisis FaktorFaktor Penyebab Kemacetan Lalulintas di Sepanjang Jalan $\mathrm{H}$ Rais A Rahman (Sui Jawi) Kota Pontianak," Jurnal Edukasi, vol. 14, no. 1, 2016. Available at: DOI 10.31571/edukasi.v14i1.292.
[2] E. Harahap, A. Harahap, A. Suryadi, D. Darmawan and R. Ceha, "LINTAS: Sistem simulasi lalu lintas menggunakan SimEvents MATLAB," 2018. Available at: http://repository.unisba.ac.id/handle/123456 789/15634.

[3] F. Umar, "Simulasi Arus Lalu Lintas di Perempatan Jalan Untuk Meminimalkan Waktu Tunggu Antrian Dengan Menggunakan ARENA," 2016. Available at: http://jrmsi.studentjournal.ub.ac.id/index.php/ irmsi/article/view/440.

[4] C. D. Leonis and others, "Usulan perbaikan sistem lalu lintas di Jalan Buah Batu dengan menggunakan simulasi," 2018.

[5] T. Salim, M. Hutagalung and H. Y. Sutarto, "Simulasi Arus Lalu Lintas Menggunakan Perangkat Lunak Simulink," Jurnal Telematika, vol. 13, pp. 7-12, 2019. Available at: https://journal.ithb.ac.id/telematika/article/vie w/254.

[6] N. Supriatna, N. C. Basjaruddin and E. Rakhman, "Cooperative Driving Pada Perempatan Jalan Berbasis Fuzzy Logic Menggunakan Komunikasi Antar Kendaraan," in Prosiding Industrial Research Workshop and National Seminar, 2017. Available at: DOI 10.35313/irwns.v8i3.709.

[7] I. Iryanto and D. Andiwijayakusuma, "Pengaturan Lampu Lalu Lintas dengan Simulasi Monte Carlo Studi Kasus: Perempatan Daerah Dago--Bandung," JTT (Jurnal Teknologi Terapan), vol. 2, 2016. Available at: DOI 10.31884/jtt.v2i2.15.

[8] R. Firmansyah, F. Baskoro and B. R. Rynaldo, "Perancangan dan Simulasi Sistem Lampu Lalu Lintas 4 Arah dengan Menggunakan Programmable logic Controller Omron CP1E dengan Tampilan Cx-Designer," INAJEEE: Indonesian Journal of Electrical and Eletronics Engineering, vol. 1, pp. 13-18, 2018. Available at: https://journal.unesa.ac.id/index.php/inajeee/ article/view/3309.

[9] S. P. Buana and B. Tulung, "Simulasi Pengaturan Lampu Lalu Lintas Berdasarkan Jam Dan Hari di Perempatan Jalan Dengan Visualisasi HMI," $2016 . \quad$ Link: 
http://etd.repository.ugm.ac.id/home/detail p encarian/105593.

[10] M. K. A. Al Mufti, W. Wahyudi and B. Setiyono, "Simulasi Lalu Lintas Simpang Empat Menggunakan Cellular Automata Dengan Sistem Kontrol Berbasis Artificial Neural Network pada Matlab," TRANSIENT, vol. 7, pp. 508-514., 2018. DOI 10.14710/transient.7.2.508-514.

[11] R. Bowden, B. K. Ghosh and C. Harrell, "Simulation using promodel," Boston: McGrawHill, 2000.

[12] S. Robinson, Simulation: the practice of model development and use, vol. 50, Wiley Chichester, 2004. Available at: DOI 10.1057/palgrave.jos. 4250031 .

[13] A. M. Law, "Simulation modeling and analysis 4th edition," The McGraw-Hill companies, 2007. Available at: https://fac.ksu.edu.sa/sites/default/files/index .pdf.

\section{Biografi penulis}

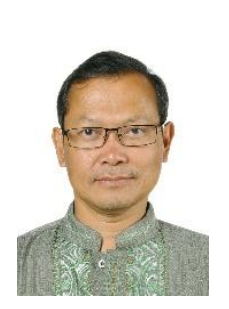

\section{Christanto Triwibisono}

Christanto Triwibisono adalah Dosen di Universitas Telkom. la menerima gelar Doktor dalam bidang Manajemen di Fakultas Ekonomi dan Bisnis, Universitas Padjadjaran, Indonesia pada 2017.
[14] S. G. Henderson and B. L. Nelson, Handbooks in operations research and management science: simulation, Elsevier, 2006. Available at: DOI doi.org/10.1016/s0927-0507(06)x1300-2 .

[15] I. Docherty and J. Shaw, Traffic jam: ten years of'sustainable'transport in the UK, Policy Press, 2008. Available at: DOI 10.1111/j.1467-9299.2010.01818_3.x.

[16] J. Sterman, Business dynamics, Irwin/McGraw-Hill c2000.., 2010. Available at: DOI 10.1057/palgrave.jors.2601336.

[17] F. N. Gustavsson, New Transportation Research Progress, New York: Nova Science Publishers, Inc, 2007.

\section{Rio Aurachman, MT}

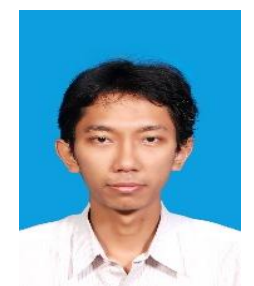

Alumni S1 Teknik Industri ITB serta S2 Teknik dan Manajemen Industri ITB. Kini menjadi dosen di Program Studi Teknik Industri Universitas Telkom dengan fokus penelitian di bidang Operation Research dan Pemodelan Sistem. 